\title{
Physiological Responses and Economics of Female Cross-Bred Calves under Different Shelter Managemental Practices in Semi- Arid Zone
}

\author{
Kailash, R.P. Jat and Rashmi Bhinda* \\ Department of Livestock Production Management, SKN Agriculture University \\ , Jobner-303329, India \\ *Corresponding author
}

\section{A B S T R A C T}

\begin{tabular}{|l|}
\hline K e y w o r d s \\
Loose house, Barn \\
house, Bedding, \\
Curtains, \\
Respiration rate, \\
Body temperature, \\
Economics, \\
Crossbred calves.
\end{tabular}

\section{Introduction}

India is a sub-tropical country where climate varies in most of its part. The main constraint in the efficient livestock production in India is climate. The climatic conditions in Rajasthan state are extremely hard both in summer and winter where ambient temperature varies from $46-48^{\circ} \mathrm{C}$ in summer and $0^{\circ} \mathrm{C}$ to $4^{\circ} \mathrm{C}$ in winter. This adverse climatic condition effects the growth and age of maturity of the calves (Antil et al., 1991). During winter, the structures especially those parts coming in contact with animal, like floors and walls, should not get too cold and provide protection from cold winds. To combat cold stress, the animal must increase its metabolic rate to supply more body heat. This increases dietary requirements, particularly for energy. Housing, feeding and managemental technologies are available through which climatic stress on animal can be reduced. The various managemental practices such as water sprinkling, air conditioning, showering and wallowing during summer (Srivastva et al., 1978). The degree of comfort depends upon 
the type of housing which indirectly affects the health of animal inhabiting it (Rokde and Tomer, 2000). Animal housing helps in moderating the range of micro-environment to which the animals are exposed and optimizes their production by protecting them from extreme climates.

A shelter is required both during summer as well as winter to counter the various vagaries of adverse climate and to provide a comfortable environment to the animals. Cows may prefer a particular housing system, which may have covered space, open area, tree shade or any other additions. Bedding helps to insulate animals from the cold ground. The calves are exposed to cold atmosphere temperature as well as wet floor which may affect their growth and health.

\section{Materials and Methods}

Fifteen crossbred (Tharparkar / Sahiwal x HF) calves (10-30 months) were taken from the dairy farm of SKN College of Agriculture, Jobner from 05-12-2014 to 05-03-2015 and divided into 3 groups of 5 animals each on the basis of their body weight and age. Each group was allotted randomly to the following housing conditions/treatments:-

\section{$T_{1}$ - Loose house (control)}

House having covered area with asbestos cement sheet roofing, brick paved floor and open area surrounded by 1.5 meter high from three sides.

\section{$\mathrm{T}_{2}$ - Loose house + Bedding + Curtains}

Bedding of left over wheat bhusa was changed at weekly intervals and loose house as detailed above in T1 was used as modification. Curtains were provided to calves at night hours for protection from cold stress.

\section{$\mathbf{T}_{3}$ Conventional Barn (closed)}

In conventional barn is completely closed structure as roofed and walls are also complete with windows and ventilators located at suitable places to get more ventilation and lighting. Animals were tied at neck by iron chains.

Crossbred calves were offered wheat straw (Triticum aestivum) ad lib.as dry fodder. The concentrate as pelleted feed (Sarus Gold) / readymade feed was formulated which contained $20.53 \% \mathrm{CP}, 2.25 \% \mathrm{EE}$ and $14.69 \%$ $\mathrm{CF}$. The animals were fed in the morning as per NRC recommendations for dairy cattle. Maximum, minimum, dry and wet bulb temperatures were recorded at 8.30 am and $3.00 \mathrm{pm}$ daily. The relative Humidity was calculated from dry and wet bulb reading using hygrometric table. The Humidity Index (THI) was calculated (MC Dowell 1972).

$\mathrm{THI}=0.72\left(\right.$ dry bulb temp. ${ }^{\circ} \mathrm{C}+$ wet bulb temp. $\left.{ }^{\circ} \mathrm{C}\right)+40.6$

The experiment was conducted in a completely randomized design (CRD) and data was statistically analyzed by standard statistical methods (Snedecor and Cochran, 1994).

\section{Results and Discussion}

\section{Microclimate in different experimental houses}

Table 1 shows that the climatic variables in different houses. The mean maximum temperature was $22.55 \pm 0.184,21.09 \pm 0.132$ and 20.61 $\pm 0.137{ }^{0} \mathrm{C}$ in $\mathrm{T}_{1}, \mathrm{~T}_{2}$ and $\mathrm{T}_{3}$, respectively. The average maximum temperature was higher $(\mathrm{P}<0.05)$ in loose house $\left(\mathrm{T}_{1}\right)$ as compared to $\mathrm{T}_{2}$ (Modified house) and $\mathrm{T}_{3}$ (Closed barn). The mean minimum temperature was $13.69 \pm 0.245$, 
$14.07 \pm 0.204$ and $15.50 \pm 0.150$ in $\mathrm{T}_{1}, \mathrm{~T}_{2}$ and $\mathrm{T}_{3}$, respectively. While minimum temperature was significantly higher $(P>0.05)$ in $T_{2}$ and $T_{3}$ was observed due to protection from cold by curtains as well as bedding in modified loose house and maximum area closed by wall in conventional barn But the minimum temperature was lower $(\mathrm{P}<0.05)$ in loose house than other groups. The mean relative humidity in $\mathrm{T}_{1}, \mathrm{~T}_{2}$ and $\mathrm{T}_{3}$ shed was $68.74 \pm 0.546,67.48 \pm 0.424$ and $72.45 \pm 1.676$ percent, respectively. The mean relative humidity was significantly higher $(\mathrm{P}<0.05)$ in conventional barn $\left(\mathrm{T}_{3}\right)$ as compared to other treatments. The mean THI values $63.59 \pm 1.256,64.30 \pm 1.138$ and $64.64 \pm 1.153$ in $\mathrm{T}_{1}, \mathrm{~T}_{2}$ and $\mathrm{T}_{3}$, respectively. The Temperature Humidity Index (THI) values were more in $\mathrm{T}_{3}$ as compared to $T_{2}$ than in $T_{1}$ treatment.

\section{Respiration rate}

The data on respiration rate recorded at fortnightly interval in different treatments. The average respiration rate (counts/ minute) in morning was $14.40 \pm 0.955,14.27 \pm 0.516$ and $15.33 \pm 0.851$ in $\mathrm{T}_{1}, \mathrm{~T}_{2}$ and $\mathrm{T}_{3}$, respectively, while the corresponding figures for evening were $14.93 \pm 0.806, \quad 14.63 \pm 0.474$ and $15.27 \pm 0.761$ counts per minute. Average daily respiration rate was $14.67 \pm 0.847,14.52 \pm$ 0.418 and $15.30 \pm 0.783$ counts per minute in respective treatments. Table 2 shows that the average respiration rate was higher $(\mathrm{P}<0.05)$ in $T_{3}$ group calves as compared to $T_{1}$ and $T_{2}$ group due to mostly wet floor and higher humidity. The respiration rate in $\mathrm{T}_{2}$ group was significantly $(\mathrm{P}<0.05)$ lower as compared to $\mathrm{T}_{1}$ and $\mathrm{T}_{3}$ due to more comfort and warmth made available through wheat straw bedding performed a protective barrier preventing further heat lost from body of calves to cool ambient atmosphere. The present findings are in agreement with the result of Chakrabarti (1991) and Singh (2000).

\section{Body temperature}

The data on rectal temperature recorded at fortnightly interval in different treatments. The mean morning rectal temperature of crossbred calves was $101.51 \pm 0.561,101.32 \pm 0.429$ and $100.81 \pm 0.494 \quad{ }^{0} \mathrm{~F} \quad$ in $\mathrm{T}_{1}, \quad \mathrm{~T}_{2}$ and $\mathrm{T}_{3}$, respectively. The corresponding values for evening were $102.06 \pm 0.462,101.74 \pm 0.502$ and $101.29 \pm 0.477^{0} \mathrm{~F}$. The average daily rectal temperature $\left({ }^{0} \mathrm{~F}\right)$ was $101.79 \pm 0.270$, $101.54 \pm 0.399$ and $101.05 \pm 0.346{ }^{0} \mathrm{~F}$ in $\mathrm{T}_{1}, \mathrm{~T}_{2}$ and $\mathrm{T}_{3}$, respectively.

Table.1 Average temperature $\left({ }^{\mathrm{O}} \mathrm{C}\right)$, relative humidity $(\mathrm{RH} \%)$ and temperate humidity index (THI) values in different houses

\begin{tabular}{|l|c|c|c|}
\hline Parameters & $\mathrm{T}_{1}$ & $\mathrm{~T}_{2}$ & $\mathrm{~T}_{3}$ \\
\hline Maximum temperature & $\mathbf{2 2 . 5 5}^{\mathbf{a}} \pm \mathbf{0 . 1 8 4}$ & $\mathbf{2 1 . 0 9}^{\mathbf{b}} \pm \mathbf{0 . 1 3 2}$ & $\mathbf{2 0 . 6 1}^{\mathbf{c}} \pm \mathbf{0 . 1 3 7}$ \\
& $(19.00-28.93)$ & $(18.07-26.67)$ & $(16.87-26.03)$ \\
\hline Minimum temperature & $\mathbf{1 3 . 6 9}^{\mathbf{c}} \pm \mathbf{0 . 2 4 5}$ & $\mathbf{1 4 . 0 7}^{\mathbf{b}} \pm \mathbf{0 . 2 0 4}$ & $\mathbf{1 5 . 5 0}^{\mathbf{a}} \pm \mathbf{0 . 1 5 0}$ \\
& $(8.59-17.69)$ & $(10.04-18.92)$ & $(10.12-20.51)$ \\
\hline Relative humidity $(\%)$ & $\mathbf{6 8 . 7 4}^{\mathbf{b}} \pm \mathbf{0 . 5 4 6}$ & $\mathbf{6 7 . 4 8}^{\mathbf{c}} \pm \mathbf{0 . 4 2 4}$ & $\mathbf{7 2 . 4 5}^{\mathrm{a}} \pm \mathbf{1 . 6 7 6}$ \\
& $(65.97-72.29)$ & $(65.39-70.50)$ & $\left(63.88^{-}-83.29\right)$ \\
\hline Temperature humidity index $(\mathrm{THI})$ & $\mathbf{6 3 . 5 9}^{\mathbf{b}} \pm \mathbf{1 . 2 5 6}$ & $\mathbf{6 4 . 3 0}^{\mathbf{a}} \pm \mathbf{1 . 1 3 8}$ & $\mathbf{6 4 . 6 4}^{\mathbf{c}} \pm \mathbf{1 . 1 5 3}$ \\
\hline & $(59.80-72.52)$ & $(58.02-71.28)$ & $(57.27-73.39)$ \\
\hline
\end{tabular}

Means having different superscript differ significantly $(\mathrm{P}<0.05)$ 
Table.2 Average respiration rate/minute and body temperature $\left({ }^{0} \mathrm{~F}\right)$ of crossbred calves

\begin{tabular}{|l|c|c|c|}
\hline Parameters & $\mathrm{T}_{1}$ & $\mathrm{~T}_{2}$ & $\mathrm{~T}_{3}$ \\
\hline Respiration rate/minute & & & \\
\hline Morning & $14.40^{\mathrm{b}} \pm 0.955$ & $14.27^{\mathrm{bc}} \pm 0.516$ & $15.33^{\mathrm{a}} \pm 0.851$ \\
\hline Evening & $14.93^{\mathrm{b}} \pm 0.806$ & $14.63^{\mathrm{c}} \pm 0.474$ & $15.27^{\mathrm{a}} \pm 0.761$ \\
\hline Average & $\mathbf{1 4 . 6 7}^{\mathrm{b}} \pm \mathbf{0 . 8 4 7}$ & $\mathbf{1 4 . 5 2}^{\mathrm{bc}} \pm \mathbf{+ 0 . 4 1 8}$ & $\mathbf{1 5 . 3 0}^{\mathrm{a}} \pm \mathbf{\pm 0 . 7 8 3}$ \\
\hline Body temperature $\left({ }^{\mathrm{o}} \mathrm{F}\right)$ & & & \\
\hline Morning & $101.51^{\mathrm{a}} \pm 0.561$ & $101.32^{\mathrm{ab}} \pm 0.429$ & $100.81^{\mathrm{c}} \pm 0.494$ \\
\hline Evening & $102.06^{\mathrm{a}} \pm 0.462$ & $101.74^{\mathrm{ab}} \pm 0.502$ & $101.29^{\mathrm{c}} \pm 0.477$ \\
\hline Average & $\mathbf{1 0 1 . 7 9}^{\mathrm{a}} \pm \mathbf{0 . 2 7 0}$ & $\mathbf{1 0 1 . 5 4}^{\mathrm{b}} \underline{\mathbf{\pm 0 . 3 9 9}}$ & $\mathbf{1 0 1 . 0 5}^{\mathrm{c}} \pm \mathbf{0 . 3 4 6}$ \\
\hline
\end{tabular}

Means having different superscript differ significantly $(\mathrm{P}<0.05)$

Table.3 Cost of calves rearing under different housing modifications

\begin{tabular}{|c|c|c|c|}
\hline Particulars & $\mathrm{T}_{1}$ & $T_{2}$ & $T_{3}$ \\
\hline 1. Cost of curtain/bedding & - & $\begin{array}{l}695 \\
(2.11)\end{array}$ & - \\
\hline 2.Cost of labour & $\begin{array}{l}5500 \\
(17.74)\end{array}$ & $\begin{array}{l}6000 \\
(18.16)\end{array}$ & $\begin{array}{l}6500 \\
(19.67)\end{array}$ \\
\hline 3. Cost of medicine & $\begin{array}{l}240 \\
(0.77)\end{array}$ & $\begin{array}{l}240 \\
(0.73)\end{array}$ & $\begin{array}{l}240 \\
(0.73)\end{array}$ \\
\hline $\begin{array}{l}\text { 4. Quantity of feed consumed (Qt) } \\
\text { i. Concentrate- } \\
\text { ii. } \quad \text { Wheat straw- }\end{array}$ & $\begin{array}{l}11.25 \\
14.48\end{array}$ & $\begin{array}{l}11.25 \\
15.62\end{array}$ & $\begin{array}{l}11.25 \\
15.92\end{array}$ \\
\hline $\begin{array}{cl}\text { 5. Cost of feed consumed (Rs.) } \\
\text { i. } & \text { Concentrate- } \\
\text { ii. } & \text { Wheat straw- } \\
\text { iii. } & \text { Total }\end{array}$ & $\begin{array}{l}14850.0 \\
10425.6 \\
25275.6 \\
(81.49)\end{array}$ & $\begin{array}{l}14850.0 \\
11246.4 \\
26096.4 \\
(79.00)\end{array}$ & $\begin{array}{l}14850.0 \\
11462.4 \\
26312.4 \\
(79.60)\end{array}$ \\
\hline $\begin{array}{l}\text { 6. Total variable cost of raising ( } 5 \\
\text { calves) }\end{array}$ & $\begin{array}{l}31015.6 \\
(100)\end{array}$ & $\begin{array}{l}33031.4 \\
(100)\end{array}$ & $\begin{array}{l}33052.4 \\
(100)\end{array}$ \\
\hline 7. Total variable cost of one calve & 6203.12 & 6606.28 & 6610.48 \\
\hline 8. Total body weight gain/ calf $(\mathrm{kg})$ & 43.6 & 51 & 50.4 \\
\hline 9. Cost $/ \mathrm{kg}$ gain & 142.27 & 129.53 & 131.16 \\
\hline
\end{tabular}

(Figures in parentheses are percentage)

Cost of items (concentrate, Dry fodder and other items in Rs./Qt.)

\begin{tabular}{|c|c|c|}
\hline S. No. & ItemsFarm Prices & \\
\hline 1. & Concentrate & @ Rs. 1320 \\
\hline 2. & Wheat straw & @ Rs.720 \\
\hline 3. & Medicine (Panacure) & @ Rs. 48/3g \\
\hline 4. & Curtain & @ Rs. 335 cost for preparing / stitching of bags \\
\hline 5 & bedding $(120 \mathrm{~kg})$ & @ Rs $3 / \mathrm{kg}$ waste straw \\
\hline 6. & Labour cost /day & @ Rs 200 \\
\hline
\end{tabular}


Table 2 revealed that the morning, evening and average rectal temperature was higher $(\mathrm{P}<0.05)$ in $\mathrm{T}_{1}$ as compared to $\mathrm{T}_{2}$ and $\mathrm{T}_{3}$ group calves. The higher rectal temperature in loose housed calves might be due to sunrays coming directly in the loose house leading to warming of shed which in correlation to maximum higher temperature. The present findings are in agreement with the result of Chakrabarti et al., (1996), and Parihar et al., (1992) reported that rectal temperature was significantly higher in morning and evening in loose house as comfort to conventional barn.

\section{Economics / variable cost}

Table 3 shows that the cost on different accounts (total cost, cost of raising per calf, cost per $\mathrm{kg}$ gain etc.) for crossbred calves rearing under different housing conditions. The total feeding cost based on farm price was Rs. 25275.6, 26096.4 and 26312.4 in $\mathrm{T}_{1}$, $\mathrm{T}_{2}$ and $\mathrm{T}_{3}$, respectively. The total variable cost per kg gain was Rs.142.27, 129.53 and 131.16 in $T_{1}, T_{2}$ and $T_{3}$, respectively. The total variable cost per calf was Rs.6203.12, 6606.28 and 6610.48 in $\mathrm{T}_{1}, \mathrm{~T}_{2}$ and $\mathrm{T}_{3}$, respectively. The higher cost in $_{3}$ group may be due to more expenditure incurred on labour and feed. The labour cost was higher in barn house group as compared to other groups. The cost per unit gain in body weight was less in $\mathrm{T}_{2}$ followed by $\mathrm{T}_{3}$ and $\mathrm{T}_{1}$. Relatively lower cost $/ \mathrm{kg}$ gain in body weight in $\mathrm{T}_{2}$ can be attributed to higher growth rate of calves in this group. The present findings are in conformity with those reported by Singh (2000) and Jat et al., (2002).

\section{References}

Antil, I.S, Yadav, R.S. and Yadav, B.L. 1991. Influences of special summer management practices on growth and feed consumption of growing buffalo calves. Indian J. Ani. Prod. Mgmt., 7:102-104.

Chakrabarti, A. 1991. Effect of winter management systems on growth performance of female Murrah buffalo calves. M.V.Sc. Thesis, Deptt. Of LPM, C.C.S. Hariyana Agriculture University, Hisar.

Chakrabarti, A., Singh, N. and Yadav, R.S. 1996. Effect of winter managemental practices systems on physiological status of female Murrah buffalo calves. Indian J. Ani. Sci., 66:78-82.

Jat, R.P., Yadav B.L. and Gupta L.R. 2002. Labour utilization patterns and economic of buffalo calves reared under different winter housing systems. Indian J. Ani. Prod. Mgmt., 18 (1-2): 32-35.

McDowell, R.E. 1972. Improvement of livestock production in warm climates. WH Freeman and Co; San Francisco. 51-53.

Parihar, A.S., Jain, P.K., Singh, H.S; Singh, V.P. and Singh, N.P. 1992. Seasonal variation in certain biochemical and hematological constituents in the blood of Surti buffaloes. Indian J. ani. Sci.,41:537-541.

Rokde S.N. and Tomar O.S. 2000. Effect of housing on incidence of diseases in crossbred Karan Swiss and Karan Fries calves. Indian Journal Animal Production Management, 16:64-65.

Shekhawat, L.S. and Chaudhary, J.L. 2012. Effect of roof modifications in loose house on intake and utilization of nutrients and milk yield in lactating crossbred cows during winter season. J. Dai. Sci., 65(6): 501-07.

Singh, Y. 2000. Effect of certain managemental practices on the performance of buffalo heifers, Ph.D. Thesis. Deptt. of LPM, Haryana Agriculture University, Hisar, India.

Snedecor, G.W. and Cochran, W.G. 1994. 
Statistical methods. $8^{\text {th }}$ Edn. Lowa, State University Press, Ames, Lowa.

Srivastava, R.K., Dhingra, D.P., Gangwar,

P.C., Soni, P.L, Mehta, S.N. and
Bahga, C.S. 1978. Effect of spray cooling and wallowing on milk yield and reproductive performance of buffaloes. J. Agri. Engi., 15: 189-196.

\section{How to cite this article:}

Kailash, R.P. Jat and Rashmi Bhinda. 2018. Physiological Responses and Economics of Female Cross-Bred Calves under Different Shelter Managemental Practices in Semi- Arid Zone. Int.J.Curr.Microbiol.App.Sci. 7(07): 484-489. doi: https://doi.org/10.20546/ijcmas.2018.707.059 